\title{
Relative Influence of Push Attributes and Pull Factors on Corporate Debt Issuance
}

\author{
Subhankar Nayak \\ Financial Services Research Centre, School of Business and Economics, Wilfrid Laurier University \\ 75 University Avenue, Waterloo, ON N2L 3C5, Canada \\ Tel: 1-519-884-0710 ext 2206 E-mail: snayak@wlu.ca
}

Received: August 17, $2010 \quad$ Accepted: September 18, $2010 \quad$ doi:10.5539/ijef.v3n2p18

\begin{abstract}
Many corporate events are self-selected, but the relative impact of internal (firm-specific) and external (environmental) influences on discretionary corporate decisions remains largely unknown. In this paper, focusing on corporate debt issuance, we apply the contemporary push-pull theory to establish whether bond issuance are pushed by the firms due to internal considerations, or pulled by the enticement of exogenous forces. We explore the impact of eight firm-specific push attributes and four systematic pull factors on the likelihood and volume of five types of debt issued, and disentangle the relative significance of push and pull effects. We find three key results. First, unconditionally, both firm-specific push attributes and exogenous pull factors are relevant. Second, the relative significance of push effects are always decidedly larger than those of pull effects. Finally, pull factors have no conditioning role in how markets react to debt issuance. Although pull effects do matter, push effects compellingly dominate.
\end{abstract}

Keywords: Push attributes, Pull factors, Push-pull theory, Corporate debts, Conditional event study

\section{Introduction}

Many corporate events are self-selected; that is, these corporate decisions are not random, arbitrary, or compelled, but are deliberate and calculated decisions by firms or corporate managers to self-select into their preferred choices while optimizing certain objectives or opportunities ( $\mathrm{Li}$ and Prabhala, 2007). Corporate managers retain a large degree of discretion in deciding whether to undertake these events and the timing of these events if undertaken. Examples of self-selected corporate decisions abound: security issuance, dividend payments, corporate restructuring, stock splits, etc. However, empirical evidence is mixed on whether the factors that condition the choice or timing of self-selected corporate events are internal (firm-specific) or external (environmental). Classical literature typically models corporate decisions as push events where the driving influence are endogenous and internal: based on firm-specific attributes, corporate managers time an event to maximize value or utility, to minimize risk, to send a credible signal, etc. However, emerging evidence suggest that corporate decisions are also pull events influenced by systematic and exogenous factors: managers are motivated to benefit from prevailing market conditions, to cater to investor preferences or "sentiment", or to respond to macro-economic forces. In this paper, focusing on corporate debt issuance, we explore the relative significance of push and pull factors (i.e., the internal and exogenous influences) in the timing of self-selected corporate events. (Note 1)

We focus specifically on corporate debt issuance for certain motivating reasons. First, the determinant factors for debt issuance remain less established and hence ideally suited for approbation of push-pull theory. Second, many empirical findings from equity literature (especially those involving behavioral pull factors) can potentially be validated based on studies of corporate bonds. Finally, unlike equity, which are homogenous, firms issue different types of bonds, and an empirical evaluation of push-pull theory may reveal what drive the choice of bond type.

Theory of capital structure owes its origin to the seminal work by Modigliani and Miller (1958) who lay down the conditions which make capital structure decisions largely irrelevant to the objectives of maximizing firm value and minimizing cost of capital. However, two caveats accompany this distinguished result. First, the proposed irrelevance is valid under a very rigid set of assumptions. Second (and more pertinent to our purposes), the irrelevance theorem does not preclude firms from issuing either equity or debt driven by certain motivating (internal or external) reasons. In other words, even under the Modigliani-Miller irrelevance framework, push and pull variables may influence corporate security issuance decisions.

Subsequent literature models capital structure and security issuance decisions mostly as push events. In particular, it 
is proposed that, motivated by valuation, risk, or signaling considerations, firms issue debt based exclusively on firm-specific performance and risk characteristics. Modigliani and Miller (1963), Miller (1977), and DeAngelo and Masulis (1980) suggest that accompanying tax benefits motivate a firm to issue debt. Recognizing that debt engenders implicit distress risk, Leland and Pyle (1977) and Ross (1977) propose that profitable and better performing firms issue debt to convey a credible signal about the firm's quality. Jensen and Meckling (1976) develop a framework whereby firms issue debt to minimize two opposite forms of agency costs. Based on cost and risk considerations, Myers and Majluf (1984) reveal an issuance pecking order where debt has higher issuance priority than equity. In short, push attributes predominantly condition debt issuance decision.

Nevertheless, the relevance of pull variables (systematic market or macro-economic factors) to debt issuance cannot be discounted. It has been conclusively established that bond returns demonstrate broad economic or business cycle effects (Fama and French, 1989) and regimes (Davies, 2008), and interest rates are predominant macro-economic factors that influence the volume and type of bond issued (Brennan and Schwartz, 1977; Brick and Palmon, 1992; Barry et al., 2008). However, very few studies explore the relevance of interest rates in conjunction with firm-specific push attributes.

Furthermore, the recent emergence of behavioral literature has added a new dimension to the relevance of pull effects to security issuance. Evidence suggest that systematic behavioral influences bear significant impact on stock returns and equity issuance. Broadly termed as "sentiment", two forms of such exogenous behavioral factors have been categorized: (a) market performance or momentum sentiment (measured as the long-term return of the aggregate stock market), and (b) investor sentiment (defined as the degree of investor optimism or pessimism). Relative to fundamentals, stocks are overpriced when sentiment is high, and underpriced when low sentiment reigns. Firms time the issuance of equity to capitalize on these misvaluations, that is, equity issuance is significantly more frequent when market performance is bullish (Lamont and Stein, 2006), when investor sentiment is optimistic and stock is overpriced (Baker and Wurgler, 2000), or in hot issuance periods (Ljungqvist et al, 2006). Moreover, in the context of equity issuance and stock returns, recent literature emphasize the predominant role of pull influences which contrast with the establish earlier evidence that enunciate the importance of push variables.

Although Nayak (2010) documents the significant impact of investor sentiment on bond prices (spreads), little is known on how these systematic behavioral factors condition debt issuance, if at all, and what is the significance of these exogenous influences relative to firm-specific attributes. In this paper, we explore the joint role of push and pull effects in corporate bond issuance. In particular, we seek to address a few specific questions. First, do systematic pull factors (specially sentiment and market momentum) retain driving influence on corporate debt issuance as well? Second, do both sets of variables (push and pull) remain relevant when conditioned simultaneously, or are push and pull effects partial or complete substitutes? Finally, if both effects are relevant, then what is the relative significance of each effect, and are the behavioral pull factors indeed the dominant (primary) causes for security issuance as claimed in recent literature?

A few compelling reasons motivate this project. First, as noted, it remains unknown whether and how systematic behavioral factors (like momentum or sentiment) influence debt issuance. In addition, it is also not known which set of variables (internal or exogenous) matter more in conditioning the decision of a firm to issue debt. Second, push and pull effects do not necessarily reconcile and may even conflict. For example, whereas push effects are motivated by optimization of value or risk in the mean-variance efficiency framework, pull motivations are largely opportunistic and orthogonal to mean-variance efficiency. Disentangling the relative significance of push and pull effects enables to clarify and reinforce fundamental corporate objectives. Third, since stocks and bonds are complementary securities, many empirical findings from equity literature (especially concerning behavioral pull effects) can be validated (or challenged) based on studies of corporate bonds. For example, market timing theory postulates that equity is more likely issued when prevailing sentiment is positive or equity is overvalued; the corroboratory expectation (that remains empirically unexplored) is that bonds are more likely issued when sentiment is negative or equity is undervalued. Finally, although undoubtedly equity issuance is influenced by pull effects, it remains unknown whether the overall capital structure decision depends on pull variables or not. For example, Baker and Wurgler (2002) implicitly assume that bond issuance is independent of sentiment and conclude on market timing effects in capital structure based on solely market timing of equity issuance. Such conclusions are not robust unless it is established that sentiment effects in bond issuance are minimal.

For our empirical investigation, we use a large sample of five types of bond issues, and define eight firm-specific push attributes and four exogenous pull factors. Using conditional event-study framework, we explore the impact of the push and pull variables on the types and amounts of debt issued, and based on three quantitative metrics, we disentangle the relative significance of push and pull effects in debt issuance decision. Our tests engender three key results. First, unconditionally, both firm-specific push attributes and exogenous pull factors are relevant to corporate 
debt issuance. Second, joint econometric tests reveal that internal push attributes bear the primary impact on the type and amount of debt issued; external pull forces depict only marginal secondary impact. The relative significance of push effects are decidedly larger than those of pull effects based on all metrics used. Finally, although pull factors (marginally) condition the issuance of debt, they bear absolutely no role in how markets react to such events. To summarize, although pull effects do matter, push effects dominate. Firm-specific characteristics and performance attributes determine the timing, type, and amount of bonds issued to a far greater extent than the enticement of exogenous forces. Corporate debts are largely pushed by the firms than pulled by the systematic market influences.

We proceed as follows. In Section 2 we specify the empirical model for self-selected events and propose three measures of relative significance. Section 3 describes the data sample and defines the push and pull variables. We summarize the results of empirical tests in Section 4. In Section 5, we address a few robustness issues. Section 6 concludes.

\section{Empirical specification and test design}

We adopt the two-stage conditional event-study model (Acharya, 1988; Prabhala, 1997; Li and Prabhala, 2007) as our base econometric model and modify it to incorporate the push and pull effects. This model, which implements Heckman's (1979) correction for selection biases in event studies, relates the decision of undertaking a self-selected event to the economic benefits arising from it and links market reaction to the information content underlying the event. In this framework, firm $i$ undertakes the event $(E V T)$ of issuing a bond of specific type if the decision variable $E B E N_{i}$ is positive, where $E B E N_{i}$ may be interpreted as the net economic benefit arising from undertaking the event $E V T$. A part of $E B E N_{i}$ is publicly known prior to the event based on an array of variables $X_{i}$ that constitute the pre-event information set. The rest of the information motivating the event, $\psi_{i}$, is firm $i$ 's private information that is unknown to market. In our extension, we define the pre-event information set $X_{i}$ that conditions the bond issuance decision as a cumulative function of firm-specific push attributes $\left(S_{i}\right)$ and systematic pull factors $(L)$ such that $X_{i}=S_{i} \cup L$. Thus, firm $i$ undertakes the bond issuance event $E V T$ if

$$
E B E N_{i}=\theta X_{i}+\psi_{i}=\gamma S_{i}+\lambda L+\psi_{i}>0
$$

where $\mathrm{E}\left(\psi_{i}\right)$, the pre-issuance expectation of the private information, is zero without loss of generality, and $X_{i}$ captures the ex ante likelihood of the event.

When the event is undertaken, it reveals more about the event firm's private information to the market. Specifically, the issuance of a bond by the firm implies that $E B E N_{i}>0 \Rightarrow \theta X_{i}+\psi_{i}>0$ $\Rightarrow \gamma S_{i}+\lambda L+\psi_{i}>0 \Rightarrow \psi_{i}>-\gamma S_{i}-\lambda L$. Accordingly, market forms revised expectations of the issuing firm's private information $\psi_{i}$ when it announces the issuance. Abnormal returns on announcement date are a reflection of market reaction to these revised expectations. That is, event announcement effect $A R_{i}$ is related to the conditional expectation of the firm's private information as follows

$$
E\left(A R_{i} \mid E V T\right)=\alpha+\beta E\left(\psi_{i} \mid \gamma S_{i}+\lambda L+\psi_{i}>0\right)+\phi L
$$

where $\beta$ captures the marginal strength of market reaction, that is, the market reaction to per unit new information revealed.

In simple words, a potential issuer's prior public information set consists of firm-specific push attributes and systematic pull factors. The firm decides to issue a bond if the net economic benefit expected based on the prior public information set and firm's own private information is perceived to be positive. As a response to the bond issuance, the market revises its expectations of the firm's latent private information set and reacts to these revised expectations revealed upon the announcement of bond issuance.

Empirical implementation involves two steps. The first stage adopts a probit model for the issuance of a bond (i.e., $E V T=0$ or 1) conditional on a set of firm-specific push attributes $S_{i}$ and systematic pull factors $L$ that characterize the bond issuance decision (equation (1)). The conditional residual from the probit model, computed as the inverse mills ratio (IMR), captures the expectation of the information revealed by the event, $E\left(\psi_{i} \mid \gamma S_{i}+\lambda L+\psi_{i}>0\right)$. The second stage involves linear regression of bond issuance announcement effects $A R_{i}$ on the endogenously computed IMR (equation (2)).

This simple framework engenders straightforward empirical tests to explore the role of push attributes and pull factors in corporate debt issuance. Whether push and pull variables bear any influence on corporate bond issuance decisions and associated market reactions can be established based on the econometric significance of the corresponding coefficients: $\gamma$ and $\lambda$ in the probit specification (1) and $\phi$ in linear regression (2). In addition, the above formulation also allows the development of quantitative metrics to assess the relative significance of push and pull effects. We develop modified versions of three common econometric measures to evaluate the relative effects. 
The first metric is the $D 1$ measure which quantifies the incremental contribution of a partial information set or a partial set of variables relative to the full information set or the complete set of variables. D1 measure for push (pull) effect is defined as

$$
D 1 \text { Measure for push (pull) effect }=1-\frac{R^{2} \text { for pull }(\text { push) model alone }}{R^{2} \text { for joint push }+ \text { pull model }}
$$

where $R^{2}$ s refer to adjusted $R^{2}$ for regressions and pseudo $R^{2}$ for probits. For example, to compute $D 1$ measure for push effect, we fit a probit model using just the pull variables, and another using jointly all push and pull variables, and plug in estimated pseudo $R^{2}$ in equation (3). The value reveals the incremental explanatory power of the push effect.

The second and third metrics are the shock and mean effects ratios which reflect the incremental impacts of shocks to and shifts in the estimated model coefficients. The two ratios are defined as

$$
\begin{aligned}
& \text { Shock ratio for push (pull) effect }=\frac{\text { Effect of } 1 \sigma \text { shock in push (pull) model }}{\text { Effect of } 1 \sigma \text { shock in push }+ \text { pull model }} \\
& \text { Mean effects ratio for push (pull) effect }=\frac{\text { Effect of } 1 \mu \text { shift in push (pull) model }}{\text { Effect of } 1 \mu \text { shift in push }+ \text { pull model }}
\end{aligned}
$$

where $\sigma$ and $\mu$ denote the standard deviations and means of the independent variables used in the regression or probit specification. Effects of $1 \sigma$ shock $(1 \mu$ shift $)$ are computed as the cumulative change in the value of the dependent decision variable arising from one standard deviation (one mean) positive change in each of the independent variables. In each ratio, the numerator is the total effect using just the push or pull variables separately and the denominator is the cumulative effect using all push and pull variables jointly.

It is worth emphasizing that (a) each of the three metrics is computed separately for push and pull effects, (b) has a numerical value ranging between 0 and 1 , and (c) the larger is the value of the metric, the greater is the relative significance of the associated effect. D1 measure reveals the relative statistical significance of push and pull variables, and shock and mean effects ratios depict the relative economic significance. (Note 2)

\section{Data and variables}

\subsection{Event Sample}

We use a large 14-year sample (covering 1994 through 2007) of corporate bond issues obtained from the Mergent Fixed Investment Securities Database (FISD). We collect issuance related information (in particular, issuance date and offer amount) on five types of bond issues: straight bonds, convertible bonds, bonds with call or put provisions, and bonds issued under SEC Rule 144A. Adopting standard norms, we exclude non-corporate bonds, foreign issues, and bonds with non-standard options and features. We also drop bond issues that are in default or possess close-to-default bond ratings.

For bond ratings, we use Standard \& Poor's (S\&P) rating if it exists; otherwise we use Moody's rating data. We convert alphanumeric ratings into integer rating values where lower rating values denote better quality (smaller default risk). Based on 6-digit CUSIP identifiers, we match the corporate bonds with the stock price data in the Center for Research in Security Prices (CRSP) database, and the financial and accounting information in Standard and Poor's Compustat database. From CRSP, for each bond issuer, we collect the time-series of daily stock returns prior to and around the bond issuance date. Compustat provides a large array of issuer-specific balance sheet and income statement variables. We focus on corporate bonds issued by publicly traded firms, and hence exclude bond issues that do not have any match in either CRSP or Compustat or those with insufficient historical data.

\subsection{Firm-specific push attributes}

The list of potential firm-specific determinants of security issuance decisions is long. However, motivated by the postulates of seminal theoretical papers on capital structure (Jensen and Meckling, 1976; Miller, 1977; Leland and Pyle, 1977; Ross, 1977; Myers and Majluf, 1984), following the recommendations of recent empirical papers (Fama and French, 2002; 2005; Goyal and Frank, 2009), and based on anecdotal evidence, we identify eight firm-specific push attributes as relevant variables. Prior evidence engender the expectation that larger and older firms with greater profitability, smaller book-to-market ratio, high current leverage, more free available cash, good credit quality ratings, and undervalued equity are more likely to issue debt (specially straight or callable bonds). On the other hand, bonds that provide additional incentives to investors (convertibles or bonds with put options) or semi-privately placed bonds (Rule 144A issues) are more likely to emanate from smaller and newer firms with relatively lower profitability, poor credit quality, and good equity performance (for timing reasons). We compute these eight 
firm-specific push attributes for each bond issuer as follows:

1. Age: listing period in CRSP in years;

2. Market capitalization: logarithm of total equity capitalization;

3. Profitability: ratio of operating income before depreciation to total assets;

4. Tobin's Q: ratio of total market value of debt and equity assets to recorded book value of assets;

5. Debt ratio: ratio of all liabilities (current and long-term) to total assets;

6. Free cash ratio: ratio of retained earnings to total assets;

7. Rating value: numerical value of the bond's credit rating; and

8. Pre-issue runup: one-year pre-issue cumulative abnormal return (CAR) computed as the sum of excess of stock returns over market (CRSP value-weighted index) returns from 250 to 3 trading days prior to the issuance day.

\subsection{Systematic pull factors}

Since interest rate is the primary macro-economic variable that bears significance for fixed income securities like corporate bonds, the two interest rate factors that are pervasively adopted in extant literature (e.g., Fama and French, 1987; 1993) are: (a) default factor (which captures the systematic credit risk or probability of default), and (b) term factor (which reflects maturity or term-structure effects of long-term interest rate curves). Furthermore, recent empirical evidence suggest that firms are more likely to issue equity when aggregate equity market demonstrates overvaluation, positive momentum or bullish performance, or when investor sentiment is optimistic (e.g., Baker and Wurgler, 2002; 2006; Lamont and Stein, 2006). By extension, these are likely determinants of bond issuance as well. Consequently, we define and use the following four systematic pull factors:

1. Default factor: computed as the difference between Moody's BAA yield and 10-year swap rate (obtained from Datastream);

2. Term factor: obtained as the difference between 10-year and 2-year swap rates (obtained from Datastream);

3. Market momentum: calculated as the aggregate return on the CRSP value-weighted index over the year prior to bond issuance; and

4. Investor sentiment index: Baker and Wurgler (2006) index that captures the systematic level of investor optimism or pessimism.

\section{Empirical results}

Our final sample consists of 6,451 bond issues (1,414 straight or plain-vanilla issues, 1,892 convertible issues, 4,262 callable bonds, 855 bonds with put options, and 2,377 bonds issued under Rule 144A) over the 14-year period from 1994 through 2007 with an average offer amount of $\$ 292.51$ million, coupon of $6.44 \%$, maturity of 12.28 years and yield spread of 73 basis points. Non-straight bond issues may possess more than one option or feature; for example, 1,448 convertibles are also callable, and 828 convertibles are issued under Rule 144A. Based on industry, the sample consists of 4,774 Industrials, 1,108 Financials and 569 utilities. These 6,451 issues belong to 2,151 unique firms with an average age of 21.92 years and equity market capitalization of $\$ 7.79$ billion.

\subsection{Relevance of push attributes and pull factors}

In the first set of empirical tests, we explore the unconditional relevance of pull factors, if any, on debt issuance activity. To this end, we construct regimes based on each of the four pull variables: based on median monthly values of default and term factors, we define two types of low-high interest rate regimes, and based on the sign of annual market momentum and sentiment index values, we designate bearish-bullish market performance and pessimistic-optimistic investor sentiment regimes. For each of the five types of bond issues, we explore the differences in the number of new issues and average volume (offer amount) under contrasting pull factor regimes. Table 1 presents the results.

The number and amount of straight bonds issued is higher when interest rates (term or default) are low or investor sentiment is optimistic; bullish equity markets also increase the number of such issues. Anecdotally, convertible and putable bonds are typically issued by firms during distressed or unfavorable periods whereby the added incentives (the right to convert the bond into equity or put back the bond to the firm) are intended to induce liquidity and investor demand. Accordingly, we find that issuance activity of convertibles and putables is significantly higher when the two interest rates are high, or investor sentiment is negative. Unlike other bond types, callables grant additional benefits (the call option) to the issuer; so firms have greater incentive to opportunistically time the callables than other bond issues. Thus, more callable bonds are issued when either investor sentiment or market 
momentum is positive, and also when prevailing interest rates are high. Finally, more bonds are issued under SEC Rule 144A when interest rates are high or markets are bullish. For all bond types, the differences in contrasting pull regimes are stronger for the number of bonds issued, and weaker when offer amounts are considered. Nevertheless, the relevance of the pull factors cannot be discount; all four pull factors bear significant impact on the number, volume and type of debt issued.

We start formal tests by carrying out separate regressions for bond issue offer amounts over the push and pull variables. Table 2 presents regression results for the five types of bonds. Panel A identifies the relevant firm-specific push attributes. Larger firms issue greater volumes of bonds of all types. Highly levered firms issue more straight, callable and Rule 144A issues. Age, credit rating, and pre-issue runup condition the amounts of convertible and callable bonds. Profitability (Tobin's Q) bear influence on the issuance of straight (putable) bonds. Panel B confirms the relevance of pull factors. Larger amounts of all five types of bonds are issued when equity markets are bearish (confirming market timing theory of equity and debt issuance) and when investor sentiment is optimistic (confirming opportunistic issuances catering to investor preferences). Default and term factors too are significant in most regressions. Comparison of Panels $\mathrm{A}$ and $\mathrm{B}$ reveal that adjusted $R^{2}$ s are significantly larger for regressions based on push variables (values range between 18-47\%) than those based on pull variables (values range between 4-14\%). Thus, on standalone basis, push attributes appear to bear significantly higher impact on the volume of debt issuance than pull variables.

The above inference is confirmed when we conduct encompassing regressions of bond issue offer amounts jointly over all push and pull variables; Table 3 reports the results. There is very little change in the significance of firm-specific push attributes from the standalone regressions (Panel A, Table 2) to joint regressions (Table 3). However, the relevance of pull factors substantially diminish in the joint specification. Term factor is never significant, and default factor is only marginally significant. The significance of momentum and sentiment factors too diminish. For all five bond types, the increase in the values of adjusted $R^{2}$ s from Panel A of Table 2 to Table 3 are very small. These results confirm that push attributes carry the first order impact on volume of debt issuance; pull factors, though not completely irrelevant, bear weak and marginal explanatory power.

Table 1 implies that the role of pull factors are more conspicuous for number of bonds issued than issue amounts; in other words, pull effects more likely influence the propensity to issue bonds of certain types than the actual offer sizes of these bonds. To establish the likelihood of issuance of debts of different types, we implement probit models for bond type (dependent variable has a value of 1 if it is an issue of a particular type, and 0 otherwise) separately over the push and pull variables. Table 4 presents the probit results for the five types of bonds. On standalone basis, almost all push attributes (Panel A) and most pull factors (Panel B) condition the likelihood of debt issuance. Market size, profitability, credit quality, market-to-book ratio, and pre-issuance runup are highly significant; age, leverage, and free cash amounts too are significant for certain bond types. Pull factors too influence the issuance of different bonds, but the role of these factors (especially investor sentiment) appear marginal. Estimated model $R^{2}$ 's are always larger for probits using push attributes ( $21 \%$ and $38 \%$ for straight and convertible bonds, and $6-8 \%$ for others) than for probits using pull factors (3-5\% for all bond types).

Table 5 documents the results of encompassing probit specifications for bond issue type implemented jointly over all push and pull variables. Comparing Tables 4 and 5, we find that although there is very little change in the significance of firm-specific push attributes from the standalone probit models to the combined probit models, the relevance of pull factors diminish in the joint specification. More compelling is the finding that, for all five bond types, the increase in the values of estimated $R^{2}$ s from Panel A of Table 4 to Table 5 are small. These results indicate that push effects are far more dominant in influencing the decision to issue bonds of different types than pull effects.

\subsection{Relative significance of push and pull effects}

Preceding results reveal that although both push and pull effects are material in the number and volume of different bonds issued, the explanatory power of push variables appear greater than those of pull variables. In this section, we formally test the relative significance of push and pull effects in debt issuance based on the metrics developed in Section 2. These tests constitute the crux of our project. Table 6 summarizes the values of different metrics quantifying the relative significance of push and pull variables.

Panel A of Table 6 reports the values of four measures of relative significance corresponding to regression models for bond issue offer amounts. Regression $R^{2}$ s based on push variables (18-47\%) are significantly larger than those based on pull variables (4-14\%); $R^{2}$ s based on the joint specification using all push and pull variables (22-48\%) are only marginally higher than those based on push variables alone. Consequently, D1 measures based on push variables are very high $(67-89 \%)$ and those based on pull variables are compellingly small (20\% for straight bonds, $1-7 \%$ for others). One positive standard deviation shocks to (or one positive mean value shifts in) different push 
variables elicit significantly greater changes in the issue offer amounts than similar shocks to (or shifts in) different pull variables. Shock ratios range between $65 \%$ to $90 \%$ for push effects and measure just $10-35 \%$ for pull effects. Mean effects ratios (91-99\% for push variables and 1-9\% for pull variables) indicate that almost all changes in debt offer volumes arise from shifts in push attributes alone.

Panel B of Table 6 presents the values of five measures of relative significance of push and pull variables in the probit models for bond issue type. Probit $R^{2}$ s based on pull variables are very low (3-5\%), and are larger for push variables (21\% and $38 \%$ for straight and convertible bonds, $6-8 \%$ for others); augmentation of pull variables to push-only model brings about just a marginal increase in $R^{2}$ s. $D 1$ measure is significantly larger for push effects (54-92\%) than for pull effects (7-44\%). Similarly, shock and mean effects ratios are dominantly larger in magnitude for push variables $(54-86 \%$ and $68-92 \%)$ than for pull variables (14-46\% and $8-32 \%)$. We compare push and pull effects based on one additional measure: the implicit probability of a particular bond type predicted by the probit model. Push attributes do a better job in predicting issue type than pull factors; $t$-tests denote that probabilities based on push factors are greater than those based on pull factors for all bond types except Rule 144A issues. However, the relevance of pull factors is not negligible: $t$-tests also reveal that predicted probabilities using all push and pull factors are always greater than those predicted based on push factors alone.

All these results conclusively confirm that although both push and pull effects are simultaneously relevant to debt issuance, firm-specific push attributes influence debt issuance decisions (in terms of number, volume and type of bond issued) to a far greater extent than exogenous pull factors. Based on three (or four for probits) different metrics, the relative explanatory power and statistical as well as economic significance of push variables are always greater than those of pull variables for different specifications for all bond types. In short, push effects dominate pull effects.

\subsection{Issuance announcement effects and the role of pull factors}

Do exogenous pull factors condition bond issuance announcement effects, that is, how markets react to issuance of bonds of different types? To this end, we implement the two-stage conditional event study framework outlined in Section 2. In the first stage, for each bond type, we fit a probit model using jointly all push and pull variables (as in Table 5). The conditional residual from the probit model, computed as the inverse mills ratio (IMR) denote the latent information content $(\psi)$ underlying the bond issuance event. Then we compute the three day announcement effect (AR) around the bond issuance date as the cumulative of excess stock returns over market index returns from one day prior to bond issuance to one day subsequent to bond issuance. In the second stage, we carry out linear regression of issuance announcement effects (AR) on latent information content (IMR) and the four pull variables. Table 7 reports the results.

Panel A of Table 7 shows that issuance of bonds always reveal significant amounts of latent private information to the market: IMR value is positive and significant for all bond types. Straight bond issues elicit no market reaction (issuance $\mathrm{AR}=0)$, but markets react negatively $(\mathrm{AR}<0)$ for bond issues of other four types; this finding is in conjunction with anecdotal evidence and extant literature.

Panel B of Table 7 documents the results of second stage regression of AR on IMR and the pull variables. Aside from a few exceptions, most pull variables remain insignificant in this regression framework. Hence, although systematic pull factors are relevant to the corporate decision of bond issuance, they have no conditioning influence on how markets react to the event of firms issuing debt. In contrast, extant equity literature (Baker and Wurgler, $2000 ; 2002)$ reveal that market reactions to equity issuance reflect prevailing systematic sentiment and perceptions.

\section{Robustness Issues}

To confirm the robustness of our findings, and to reinforce the significance and pervasiveness of our conclusions, we conduct several additional tests.

1. We use alternate firm-specific push attributes such as equity beta, price-earnings ratio, dividend-paying status, and more accounting measures. We define additional systematic pull variables such as GDP growth rate, inflation, and industrial productivity. We compute default and term factors based on Treasury rates instead of swap rates, and instead of Baker-Wurgler sentiment index we use the closed-end fund discount rate. We also compute pre-issuance runup and issuance announcement effect based on buy-and-hold returns (BHAR) approach instead of cumulative abnormal returns (CAR) method. We do not tabulate these additional results for brevity, but all results reported in this paper and consequent conclusions remain largely and effectively unaltered. The additional variables and the modified definitions bear almost no impact on any of the results.

2. The chosen sample period (1994-2007) coincides with very dramatic and unique upheavals in the financial markets. We sub-divide our sample into four sub-periods - 1994-1999 (tech bubble expansion), 2000-2002 (post-bubble collapse), 2003-2005 (high growth), and 2006-2007 (credit crisis) - and repeat all tests. Across the four 
sub-periods, we find very little difference in the relevance of the variables (regression and probit coefficients in Tables II through V) or in their relative significance (different measures in Table VI).

3. Since bonds are inherently more illiquid, recent literature reveal that bond liquidity and equity volatility are significant determinants of bond prices (spreads). To explore whether these variables also impact the issuance of bonds, we replicate our tests using two additional push attributes (Amihud bond liquidity measure and idiosyncratic equity volatility) and two new pull factors (VIX and systematic liquidity index). All four variables remain insignificant in all regression and probit specifications and hence bear no material impact on the conclusions.

4. We also briefly explore the role of the selected push and pull variables in the issuance of equity and on the overall capital structure decisions of the bond issuing firms. We find that the relevance of systematic pull factors is even lower for equity issuance. This unique results merits detailed analysis beyond the scope of the current paper and hence is the focus of a separate ongoing project.

\section{Conclusions}

Most corporate events are self-selected; corporate managers retain a large degree of discretionary flexibility in deciding whether to undertake these events and the timing and accompanying characteristics of these events if undertaken. However, literature is inconclusive regarding the source of the factors that drive the decision of self-selected corporate events, that is, whether the driving influences are internal (firm-specific) or external (environmental). Although classical literature typically models corporate decisions as driven by internal firm-specific considerations, emerging evidence suggest that corporate decisions are also influenced by systematic and exogenous variables.

In this paper, focusing on the event of corporate debt issuance, we apply the hitherto unexplored push-pull theory to corporate finance setup: that is, whether the self-selected corporate events like the type (and amount) of bonds issued are pushed by the firms due to internal considerations, or pulled by the enticement of exogenous and systematic forces. We base our empirical investigation on a large sample of five different types of bonds, and investigate the role of eight firm-specific push attributes and four exogenous pull factors in conditioning the type and amounts of different bond issues. Using a modified econometric framework, we explore the joint impact of push and pull variables on debt issuance, and we adopt three quantitative metrics that allows to disentangle the relative significance of push and pull effects.

Our results engender three key conclusions. First, unconditionally, both firm-specific push attributes and exogenous pull factors are relevant to corporate debt issuance. Second, joint econometric tests reveal that internal push attributes bear the first order impact on the type and amount of debt issued; external pull forces have only marginal secondary impact. The relative significance of push effects are pervasively greater than those of pull effects based on all adopted metrics (D1 measure, shock ratio, mean effects ratio, and predicted event probabilities). Finally, although pull factors marginally condition the issuance of debt, they bear almost no role in how markets react to such events.

In short, although pull effects do matter, push effects dominate. Corporate debts are largely pushed by the firms than pulled by the exogenous influences.

\section{References}

Acharya, S. (1988). A generalized econometric model and tests of a signaling hypothesis with two discreet signals. Journal of Finance, 43, pp. 413-429.

Baker, M. P. \& Wurgler, J. A. (2000). The equity share in new issues and aggregate stock returns. Journal of Finance, 55, pp. 2219-2257.

Baker, M. P. \& Wurgler, J. A. (2002). Market timing and capital structure. Journal of Finance, 57, pp. 1-32.

Baker, M. P. \& Wurgler, J. A. (2006). Investor sentiment and the cross-section of stock returns. Journal of Finance, 61, pp. 1645-1680.

Barry, C. B., Mann, S. C., Mihov, V., \& Rodriguez, M. (2008). Corporate debt issuance and the historical level of interest rates. Financial Management, 37, pp. 413-430.

Brennan, M.J., \& Schwartz, E.S. (1977). Convertible bonds: Valuation and optimal strategies for call and conversion. Journal of Finance, 32, pp. 1699-1715.

Brick, I. \& Palmon, O. (1992). Interest rate fluctuations and the advantage of long-term debt financing: A note on the effect of the tax-timing option. Financial Review, 27, pp. 467-474.

Davies, A. (2008). Credit spread determinants: An 85 year perspective. Journal of Financial Markets, 11, pp. 180-197. 
DeAngelo, H., \& Masulis, R. W. (1980). Optimal capital structure under corporate and personal taxation. Journal of Financial Economics, 8, pp. 3-29.

Fama, E. F., \& French, K. R. (1989). Business conditions and the expected returns on bonds and stocks. Journal of Financial Economics, 25, pp. 23-49.

Fama, E. F., \& French, K. R. (1993). Common risk factors in the returns on stocks and bonds. Journal of Financial Economics, 33, pp. 3-56.

Fama, E. F., \& French, K. R. (2002). Testing tradeoff and pecking order predictions about dividends and debt. Review of Financial Studies, 15, pp. 1-37.

Fama, E. F., \& French, K. R. (2005). Financing decisions: Who issues stock? Journal of Financial Economics, 76, pp. 549-582.

Goyal, V. K., \& Frank, M. Z. (2009). Capital structure decisions: Which factors are reliably important? Financial Management, 38, pp. 1-37.

Heckman, J. (1979). Sample selection bias as a specification error. Econometrica, 47, pp. 153-161.

Jensen, M. C., \& Meckling, W. H. (1976). Theory of the firm: Managerial behavior, agency costs and ownership structure. Journal of Financial Economics, 3, pp. 305-360.

Lamont, O.A., \& Stein, J. C. (2006) Investor sentiment and corporate finance: Micro and macro. American Economic Review, 96, pp. 147-151.

Lee, E. S. (1966). A theory of migration. Demography, 3, pp. 47-57.

Leland, H. E. \& Pyle, D. H. (1977). Informational asymmetries, financial structure, and financial intermediation. Journal of Finance, 32, pp. 371-387.

Li, K., \& Prabhala, N. R. (2007). Self-selection models in corporate finance. In B. E. Eckbo (Ed.), Handbook of Corporate Finance Vol. I, North Holland: Amsterdam, pp. 37-86.

Ljungqvist, A. P., Nanda, V. \& Singh, R. (2006). Hot markets, investor sentiment, and IPO pricing. Journal of Business, 79, pp. 1667-1702.

Miller, M. H. (1977). Debt and taxes. Journal of Finance, 32, pp. 261-275.

Modigliani, F., \& Miller, M. H. (1958). The cost of capital, corporation finance and the theory of investment. American Economic Review, 48, pp. 261-297.

Modigliani, F., \& Miller, M. H. (1963). Corporate income taxes and the cost of capital: A correction. American Economic Review, 53, pp. 433-443.

Myers, S. \& Majluf, N. S. (1984). Corporate financing and investment decisions when firms have information that investors do not have. Journal of Financial Economics, 13, pp. 187-221.

Nayak, S. (2010). Investor sentiment and corporate bond yield spreads. Review of Behavioral Finance, forthcoming.

Prabhala, N. R. (1997). Conditional methods in event-studies and an equilibrium oriented justification for using standard event-study procedures. Review of Financial Studies, 10, pp. 1-38.

Ross, S. A. (1977). The determination of financial structure: The incentive-signaling approach. Bell Journal of Economics, 8, pp. 23-40.

Shultz, K. S., Morton, K. R., \& Weckerle, J. R. (1998). The influence of push and pull factors on voluntary and involuntary early retirees' retirement decision and adjustment. Journal of Vocational Behavior, 53, pp. 45-57.

\section{Notes}

Note 1. Push-pull theory, although nascent in finance setup, is popular in sociology literature [e.g., phenomena like human migration (Lee, 1966) are caused by either push forces (repulsion of source region) or pull forces (enticement of target destination)] and in welfare economics [e.g., retirement decisions are push-pull decisions: older workers are either pushed to retire by their employer or pulled to the choice by the post-retirement enticements (Shultz et al., 1998)]. Analogously, extending the theory to finance, we envision corporate events being either "pushed by the firms" or "pulled by the market".

Note 2. For example, hypothetically if pull factors are completely irrelevant and only push attributes matter, then all three metrics will bear a value of 1 for push effects and a value of 0 for pull effects. 
Table 1. Number and volume of bonds issued under different pull factor regimes

\begin{tabular}{|c|c|c|c|c|c|c|c|c|c|c|}
\hline \multirow{3}{*}{$\begin{array}{l}\text { Pull Factor } \\
\text { Regime }\end{array}$} & \multicolumn{10}{|c|}{ Bond Type } \\
\hline & \multicolumn{2}{|c|}{ Straight } & \multicolumn{2}{|c|}{ Convertible } & \multicolumn{2}{|c|}{ Callable } & \multicolumn{2}{|c|}{ Putable } & \multicolumn{2}{|c|}{ Rule 144A } \\
\hline & Number & Amount & Number & Amount & Number & Amount & Number & Amount & Number & Amount \\
\hline \multicolumn{11}{|c|}{ Panel A: Default factor } \\
\hline low & 949 & 262.77 & 756 & 303.45 & 1,948 & 254.27 & 296 & 322.96 & 909 & 295.90 \\
\hline high & 465 & 307.54 & 1,136 & 311.14 & 2,314 & 331.62 & 559 & 401.21 & 1,468 & 320.36 \\
\hline difference & 0.000 & 0.011 & 0.000 & 0.687 & 0.000 & 0.000 & 0.000 & 0.028 & 0.000 & 0.084 \\
\hline \multicolumn{11}{|c|}{ Panel B: Term factor } \\
\hline low & 757 & 312.11 & 797 & 330.35 & 2,146 & 288.56 & 287 & 380.55 & 1,090 & 321.62 \\
\hline high & 657 & 237.62 & 1,095 & 291.85 & 2,116 & 304.09 & 568 & 370.88 & 1,287 & 302.01 \\
\hline difference & 0.008 & 0.000 & 0.000 & 0.042 & 0.646 & 0.123 & 0.000 & 0.788 & 0.000 & 0.156 \\
\hline \multicolumn{11}{|c|}{ Panel C: Market momentum (1-year return on CRSP value-weighted index) } \\
\hline negative & 160 & 296.54 & 487 & 403.97 & 999 & 385.08 & 189 & 648.81 & 672 & 367.49 \\
\hline positive & 1,254 & 275.07 & 1,405 & 274.83 & 3,263 & 269.08 & 666 & 296.17 & 1,705 & 288.74 \\
\hline difference & 0.000 & 0.410 & 0.000 & 0.000 & 0.000 & 0.000 & 0.000 & 0.000 & 0.000 & 0.000 \\
\hline \multicolumn{11}{|c|}{ Panel D: Baker-Wurgler investor sentiment index } \\
\hline negative & 527 & 226.76 & 1,064 & 254.28 & 1,820 & 285.21 & 558 & 284.84 & 1,218 & 290.05 \\
\hline positive & 887 & 307.64 & 828 & 377.18 & 2,442 & 304.51 & 297 & 541.87 & 1,159 & 333.03 \\
\hline difference & 0.000 & 0.000 & 0.000 & 0.000 & 0.000 & 0.058 & 0.000 & 0.000 & 0.226 & 0.002 \\
\hline
\end{tabular}

Table 1 reports the number of new bonds issued and the average offer amount (in $\$$ million) for five different types of bonds under different pull factor regimes over the period 1994-2007. The four panels correspond to regimes formed based on four pull factors. Each month is classified as low or high regime based on comparison with median values of monthly default and term factors. Each year is designated as negative or positive regime based on the values of preceding annual stock market momentum and concurrent Baker-Wurgler investor sentiment index. The last row of each panel reports the $p$-values corresponding to tests of significance of differences in the number or amount of bond issues under contrasting regimes. Tests of differences are based on Pearson $\chi^{2}$ test for number of issues and $t$-test for offer amount. 
Table 2. Regression of issuance volume, separate specifications for push \& pull variables

\begin{tabular}{|c|c|c|c|c|c|}
\hline \multirow[b]{2}{*}{ Variable } & \multicolumn{5}{|c|}{ Bond Type } \\
\hline & Straight & Convertible & Callable & Putable & Rule 144A \\
\hline \multicolumn{6}{|c|}{ Panel A: Regression over push attributes } \\
\hline \multirow[t]{2}{*}{ Age } & 0.03 & $2.01 * * *$ & -0.19 & 0.65 & -0.11 \\
\hline & $(0.06)$ & $(3.74)$ & $(-0.76)$ & $(0.74)$ & $(-0.30)$ \\
\hline \multirow[t]{2}{*}{ Market cap } & $85.7 * * *$ & $183.3 * * *$ & $111.7 * * *$ & $215.0 * * *$ & $122.5^{* * *}$ \\
\hline & $(14.32)$ & $(30.41)$ & $(32.62)$ & $(16.69)$ & $(27.47)$ \\
\hline \multirow[t]{2}{*}{ Profitability } & $-307.90^{*}$ & 9.20 & 24.10 & -13.90 & 30.40 \\
\hline & $(-2.01)$ & $(0.19)$ & $(0.60)$ & $(-0.11)$ & $(0.63)$ \\
\hline \multirow[t]{2}{*}{ Tobin's Q } & 16.96 & 4.36 & 1.54 & $37.73 * * *$ & 3.17 \\
\hline & $(1.24)$ & $(1.29)$ & $(0.52)$ & $(3.75)$ & $(0.79)$ \\
\hline \multirow[t]{2}{*}{ Debt ratio } & $258.7 * * *$ & 43.2 & $125.7 * * *$ & 96.9 & $106.8 * * *$ \\
\hline & $(6.16)$ & $(1.51)$ & $(6.01)$ & $(1.41)$ & $(4.20)$ \\
\hline \multirow[t]{2}{*}{ Free cash ratio } & -26.99 & -5.18 & 2.54 & 13.35 & 3.37 \\
\hline & $(-0.55)$ & $(-0.89)$ & $(0.44)$ & $(1.32)$ & $(0.49)$ \\
\hline \multirow[t]{2}{*}{ Rating value } & 0.74 & $-3.33 * * *$ & $1.63^{*}$ & 0.93 & -1.32 \\
\hline & $(0.45)$ & $(-3.60)$ & $(2.33)$ & $(0.53)$ & $(-1.45)$ \\
\hline \multirow[t]{2}{*}{ Pre-issue runup } & -0.62 & $-0.91 * * *$ & $-0.18^{*}$ & -0.31 & $-0.32 * *$ \\
\hline & $(-1.89)$ & $(-7.99)$ & $(-1.97)$ & $(-0.99)$ & $(-2.86)$ \\
\hline \multirow[t]{2}{*}{ Intercept } & $-1727.7 * * *$ & $-3497.3 * * *$ & $-2137.3 * * *$ & $-4357.6 * * *$ & $-2287.3 * * *$ \\
\hline & $(-12.83)$ & $(-26.16)$ & $(-27.73)$ & $(-15.06)$ & $(-23.06)$ \\
\hline Adjusted $R^{2}$ & 0.180 & 0.471 & 0.270 & 0.363 & 0.317 \\
\hline \multicolumn{6}{|c|}{ Panel B: Regression over pull factors } \\
\hline \multirow[t]{2}{*}{ Default factor } & $155.7 * * *$ & 65.8 & $85.1 * * *$ & $220.2 * *$ & 45.6 \\
\hline & $(5.16)$ & $(1.61)$ & $(4.17)$ & $(2.97)$ & $(1.51)$ \\
\hline \multirow[t]{2}{*}{ Term factor } & $-50.78^{*}$ & $-48.18^{*}$ & $-34.22 * *$ & -52.77 & $-48.64 * *$ \\
\hline & $(-2.45)$ & $(-2.40)$ & $(-3.17)$ & $(-1.45)$ & $(-3.22)$ \\
\hline \multirow[t]{2}{*}{ Market momentum } & $-1.73^{*}$ & $-3.19 * * *$ & $-2.50 * * *$ & $-4.01 * *$ & $-2.77 * * *$ \\
\hline & $(-2.38)$ & $(-3.99)$ & $(-6.11)$ & $(-2.89)$ & $(-4.64)$ \\
\hline \multirow[t]{2}{*}{ Investor sentiment } & $155.3 * * *$ & $78.9 * * *$ & $51.2 * * *$ & $245.1 * * *$ & $42.4 * *$ \\
\hline & $(8.30)$ & $(4.73)$ & $(5.33)$ & $(7.11)$ & $(3.11)$ \\
\hline \multirow[t]{2}{*}{ Intercept } & $98.7^{*}$ & $274.1 * * *$ & $212.4 * * *$ & 116.1 & $308.2 * * *$ \\
\hline & $(2.43)$ & (4.92) & $(7.37)$ & $(1.20)$ & $(7.25)$ \\
\hline Adjusted $R^{2}$ & 0.073 & 0.053 & 0.048 & 0.141 & 0.043 \\
\hline
\end{tabular}

$* p$-value $<0.05 ; * * p$-value $<0.01 ; * * * p$-value $<0.001$

Table 2 reports the results (coefficients and $t$-statistics in parentheses) of regressions of bond issue offer amounts (in $\$$ million) over firm-specific push attributes (Panel A) and systematic pull factors (Panel B) for the period 1994-2007. Variables are defined in sections 3.2 and 3.3. 
Table 3. Regression of issuance volume, joint specification for push \& pull variables

\begin{tabular}{|c|c|c|c|c|c|}
\hline \multirow[b]{2}{*}{ Variable } & \multicolumn{5}{|c|}{ Bond Type } \\
\hline & Straight & Convertible & Callable & Putable & Rule 144A \\
\hline \multirow[t]{2}{*}{ Age } & -0.07 & $2.29 * * *$ & -0.25 & 1.06 & -0.09 \\
\hline & $(-0.19)$ & $(4.26)$ & $(-1.01)$ & $(1.21)$ & $(-0.25)$ \\
\hline \multirow[t]{2}{*}{ Market cap } & $82.4 * * *$ & $179.5^{* * *}$ & $108.5^{* * *}$ & $199.1 * * *$ & $119.7 * * *$ \\
\hline & (14.09) & $(29.56)$ & $(31.97)$ & $(15.24)$ & $(26.68)$ \\
\hline \multirow[t]{2}{*}{ Profitability } & -250.50 & 13.40 & 42.50 & -33.90 & 35.24 \\
\hline & $(-1.67)$ & $(0.28)$ & $(1.07)$ & $(-0.28)$ & $(0.73)$ \\
\hline \multirow[t]{2}{*}{ Tobin's Q } & 6.82 & 0.55 & 1.08 & $31.40 * *$ & 0.38 \\
\hline & $(0.51)$ & $(0.16)$ & $(0.36)$ & $(3.13)$ & $(0.09)$ \\
\hline \multirow[t]{2}{*}{ Debt ratio } & $206.8 * * *$ & 41.5 & $123.1 * * *$ & 109.3 & $105.5 * * *$ \\
\hline & $(4.96)$ & $(1.45)$ & $(5.96)$ & $(1.62)$ & (4.16) \\
\hline \multirow[t]{2}{*}{ Free cash ratio } & -50.60 & -8.79 & 0.67 & 8.48 & 0.48 \\
\hline & $(-1.05)$ & $(-1.49)$ & $(0.12)$ & $(0.85)$ & $(0.07)$ \\
\hline \multirow[t]{2}{*}{ Rating value } & 1.18 & $-3.16 * * *$ & $1.91 * *$ & 2.87 & -0.87 \\
\hline & $(0.73)$ & $(-3.37)$ & $(2.76)$ & $(1.62)$ & $(-0.95)$ \\
\hline \multirow[t]{2}{*}{ Pre-issue runup } & -0.58 & $-0.94 * * *$ & $-0.23 * *$ & -0.55 & $-0.35 * *$ \\
\hline & $(-1.83)$ & $(-7.67)$ & $(-2.60)$ & $(-1.73)$ & $(-3.08)$ \\
\hline \multirow[t]{2}{*}{ Default factor } & $93.2 * * *$ & -0.1 & $36.7^{*}$ & $147.3^{*}$ & 0.7 \\
\hline & $(3.30)$ & $(-0.00)$ & $(2.07)$ & $(2.32)$ & $(0.03)$ \\
\hline \multirow[t]{2}{*}{ Term factor } & -16.77 & -18.67 & -7.80 & -27.09 & -9.08 \\
\hline & $(-0.86)$ & $(-1.23)$ & $(-0.82)$ & $(-0.87)$ & $(-0.70)$ \\
\hline \multirow[t]{2}{*}{ Market momentum } & $-1.72 * *$ & -0.83 & $-2.04 * * *$ & -1.14 & $-1.44 * *$ \\
\hline & $(-2.58)$ & $(-1.37)$ & $(-5.74)$ & $(-0.95)$ & $(-2.86)$ \\
\hline \multirow[t]{2}{*}{ Investor sentiment } & $132.4 * * *$ & $30.6^{*}$ & $26.5^{* *}$ & $114.8^{* * *}$ & $30.6^{*}$ \\
\hline & $(7.63)$ & $(2.15)$ & $(3.05)$ & $(3.60)$ & $(2.53)$ \\
\hline \multirow[t]{2}{*}{ Intercept } & $-1740.7 * * *$ & $-3391.7 * * *$ & $-2106.2 * * *$ & $-4241.2 * * *$ & $-2213.1 * * *$ \\
\hline & $(-12.91)$ & $(-24.05)$ & $(-26.29)$ & $(-14.10)$ & $(-20.64)$ \\
\hline Adjusted $R^{2}$ & 0.224 & 0.477 & 0.291 & 0.387 & 0.326 \\
\hline
\end{tabular}

$* p$-value $<0.05 ; * * p$-value $<0.01 ; * * *$-value $<0.001$

Table 3 reports the results (coefficients and $t$-statistics in parentheses) of regressions of bond issue offer amounts (in $\$$ million) jointly over firm-specific push attributes and systematic pull factors for the period 1994-2007. Variables are defined in sections 3.2 and 3.3. 
Table 4. Probit model for bond type, separate specifications for push \& pull variables

\begin{tabular}{|c|c|c|c|c|c|}
\hline \multirow[b]{2}{*}{ Variable } & \multicolumn{5}{|c|}{ Bond Type } \\
\hline & Straight & Convertible & Callable & Putable & Rule 144A \\
\hline \multicolumn{6}{|c|}{ Panel A: Probit using push attributes } \\
\hline \multirow[t]{2}{*}{ Age } & 0.0003 & $-0.0066^{* * *}$ & -0.0018 & $-0.0030^{*}$ & $-0.0037 * * *$ \\
\hline & $(0.33)$ & $(-5.35)$ & $(-1.92)$ & $(-2.45)$ & $(-3.88)$ \\
\hline \multirow[t]{2}{*}{ Market cap } & $0.197 * * *$ & $0.102 * * *$ & $-0.198 * * *$ & $0.117 * * *$ & $-0.098 * * *$ \\
\hline & $(12.45)$ & $(6.51)$ & $(-15.05)$ & $(7.22)$ & $(-7.76)$ \\
\hline \multirow[t]{2}{*}{ Profitability } & $-0.95 * *$ & $-1.13 * * *$ & $1.44 * * *$ & $0.95^{* * *}$ & $1.09 * * *$ \\
\hline & $(-2.97)$ & $(-5.06)$ & $(8.95)$ & $(4.97)$ & $(7.20)$ \\
\hline \multirow[t]{2}{*}{ Tobin's Q } & $-0.27 * * *$ & $0.16^{* * *}$ & $0.07 * * *$ & $-0.05 * * *$ & -0.01 \\
\hline & $(-8.59)$ & $(8.41)$ & $(4.75)$ & $(-3.38)$ & $(-0.64)$ \\
\hline \multirow[t]{2}{*}{ Debt ratio } & $0.48^{* * *}$ & $-1.24 * * *$ & -0.03 & $-0.66 * * *$ & 0.03 \\
\hline & $(4.21)$ & $(-12.26)$ & $(-0.32)$ & $(-6.61)$ & $(0.37)$ \\
\hline \multirow[t]{2}{*}{ Free cash ratio } & $0.25^{*}$ & $-0.14 * *$ & 0.04 & $-0.07 * *$ & -0.03 \\
\hline & $(2.50)$ & $(-3.18)$ & $(1.86)$ & $(-2.85)$ & $(-1.45)$ \\
\hline \multirow[t]{2}{*}{ Rating value } & $-0.075^{* * *}$ & $0.109 * * *$ & $0.014 * * *$ & $0.044 * * *$ & $0.022 * * *$ \\
\hline & $(-16.49)$ & $(33.03)$ & $(5.04)$ & $(15.39)$ & $(8.86)$ \\
\hline \multirow[t]{2}{*}{ Pre-issue runup } & $-0.0032 * * *$ & $0.0036^{* * *}$ & $0.0019 * * *$ & 0.0009 & $0.0029 * * *$ \\
\hline & $(-5.41)$ & $(8.08)$ & $(4.93)$ & $(1.95)$ & $(8.03)$ \\
\hline \multirow[t]{2}{*}{ Intercept } & $-3.91 * * *$ & $-3.96 * * *$ & $4.30^{* * *}$ & $-4.02 * * *$ & $1.38 * * *$ \\
\hline & $(-10.85)$ & $(-11.20)$ & $(14.43)$ & $(-10.97)$ & $(4.84)$ \\
\hline Pseudo $R^{2}$ & 0.214 & 0.378 & 0.075 & 0.076 & 0.060 \\
\hline \multicolumn{6}{|c|}{ Panel B: Probit using pull factors } \\
\hline \multirow[t]{2}{*}{ Default factor } & $-0.89 * * *$ & -0.09 & $0.67 * * *$ & $-0.33 * * *$ & $0.66^{* * *}$ \\
\hline & $(-11.99)$ & $(-1.38)$ & $(10.17)$ & $(-4.14)$ & $(10.09)$ \\
\hline \multirow[t]{2}{*}{ Term factor } & $0.09 *$ & $0.31 * * *$ & -0.03 & $0.44^{* * *}$ & $-0.09 *$ \\
\hline & $(2.18)$ & $(8.48)$ & $(-0.79)$ & $(10.08)$ & $(-2.50)$ \\
\hline \multirow[t]{2}{*}{ Market momentum } & -0.0002 & $-0.0062 * * *$ & $0.0049 * * *$ & $-0.0032 *$ & -0.0001 \\
\hline & $(-0.15)$ & $(-4.52)$ & $(3.60)$ & $(-1.98)$ & $(-0.06)$ \\
\hline \multirow[t]{2}{*}{ Investor sentiment } & -0.049 & 0.010 & $0.180 * * *$ & $-0.121 * *$ & $-0.164 * * *$ \\
\hline & $(-1.35)$ & $(0.31)$ & $(5.40)$ & $(-2.77)$ & $(-4.91)$ \\
\hline \multirow[t]{2}{*}{ Intercept } & $0.44 * * *$ & $-0.65 * * *$ & $-0.64 * * *$ & $-1.03 * * *$ & $-1.23 * * *$ \\
\hline & $(4.44)$ & $(-7.16)$ & $(-7.08)$ & $(-9.44)$ & $(-13.51)$ \\
\hline Pseudo $R^{2}$ & 0.053 & 0.032 & 0.028 & 0.047 & 0.049 \\
\hline
\end{tabular}

$* p$-value $<0.05 ; * * p$-value $<0.01 ; * * * p$-value $<0.001$

Table 4 reports the results (coefficients and $Z$-statistics in parentheses) of probit models for bond issue type (binary 0 and 1 ) over firm-specific push attributes (Panel A) and systematic pull factors (Panel B) for the period 1994-2007. Variables are defined in sections 3.2 and 3.3. 
Table 5. Probit model for bond type, joint specification for push \& pull variables

\begin{tabular}{|c|c|c|c|c|c|}
\hline \multirow[b]{2}{*}{ Variable } & \multicolumn{5}{|c|}{ Bond Type } \\
\hline & Straight & Convertible & Callable & Putable & Rule 144A \\
\hline \multirow[t]{2}{*}{ Age } & 0.0013 & $-0.0080 * * *$ & $-0.0024^{*}$ & $-0.0041^{* *}$ & $-0.0046^{* * *}$ \\
\hline & $(1.19)$ & $(-6.30)$ & $(-2.58)$ & $(-3.23)$ & $(-4.73)$ \\
\hline \multirow[t]{2}{*}{ Market cap } & $0.209 * * *$ & $0.108 * * *$ & $-0.199 * * *$ & $0.137 * * *$ & $-0.104 * * *$ \\
\hline & $(12.90)$ & $(6.65)$ & $(-14.93)$ & $(8.13)$ & $(-8.08)$ \\
\hline \multirow[t]{2}{*}{ Profitability } & $-1.16^{* * *}$ & $-1.24 * * *$ & $1.52 * * *$ & $1.01 * * *$ & $1.10^{* * *}$ \\
\hline & $(-3.53)$ & $(-5.39)$ & $(9.35)$ & $(5.21)$ & $(7.17)$ \\
\hline \multirow[t]{2}{*}{ Tobin's Q } & $-0.27 * * *$ & $0.20 * * *$ & $0.06 * * *$ & -0.02 & 0.02 \\
\hline & $(-8.61)$ & $(10.12)$ & $(4.46)$ & $(-1.21)$ & $(1.44)$ \\
\hline \multirow[t]{2}{*}{ Debt ratio } & $0.58 * * *$ & $-1.23 * * *$ & -0.05 & $-0.61 * * *$ & 0.05 \\
\hline & $(5.00)$ & $(-11.84)$ & $(-0.65)$ & $(-5.94)$ & $(0.67)$ \\
\hline \multirow[t]{2}{*}{ Free cash ratio } & $0.27 * *$ & $-0.12 * *$ & 0.04 & $-0.05^{*}$ & -0.01 \\
\hline & $(2.63)$ & $(-2.65)$ & $(1.83)$ & $(-1.98)$ & $(-0.55)$ \\
\hline \multirow[t]{2}{*}{ Rating value } & $-0.074 * * *$ & $0.111 * * *$ & $0.014 * * *$ & $0.042 * * *$ & $0.020 * * *$ \\
\hline & $(-16.06)$ & $(32.61)$ & $(5.04)$ & $(14.27)$ & $(7.70)$ \\
\hline \multirow[t]{2}{*}{ Pre-issue runup } & $-0.0023 * * *$ & $0.0028^{* * *}$ & $0.0012 * *$ & 0.0002 & $0.0028 * * *$ \\
\hline & $(-3.73)$ & $(6.03)$ & (2.96) & $(0.33)$ & $(7.65)$ \\
\hline \multirow[t]{2}{*}{ Default factor } & $-1.07 * * *$ & 0.07 & $0.73 * * *$ & $-0.32 * * *$ & $0.74 * * *$ \\
\hline & $(-13.01)$ & $(0.88)$ & (10.69) & $(-3.84)$ & $(10.87)$ \\
\hline \multirow[t]{2}{*}{ Term factor } & $0.22 * * *$ & $0.26^{* * *}$ & $-0.09 *$ & $0.44 * * *$ & $-0.18 * * *$ \\
\hline & $(4.69)$ & $(5.75)$ & $(-2.29)$ & $(9.66)$ & $(-4.78)$ \\
\hline \multirow[t]{2}{*}{ Market momentum } & 0.0006 & $-0.0076^{* * *}$ & $0.0044 * *$ & -0.0031 & -0.0010 \\
\hline & $(0.33)$ & $(-4.46)$ & $(3.13)$ & $(-1.80)$ & $(-0.69)$ \\
\hline \multirow[t]{2}{*}{ Investor sentiment } & $-0.111^{*}$ & 0.007 & $0.206^{* * *}$ & -0.077 & $-0.189 * * *$ \\
\hline & $(-2.57)$ & $(0.16)$ & $(5.77)$ & $(-1.66)$ & $(-5.25)$ \\
\hline \multirow[t]{2}{*}{ Intercept } & $-2.87 * * *$ & $-4.44 * * *$ & $3.26 * * *$ & $-4.40 * * *$ & 0.60 \\
\hline & $(-7.53)$ & $(-11.52)$ & $(10.36)$ & $(-11.05)$ & $(1.95)$ \\
\hline Adjusted $R^{2}$ & 0.263 & 0.408 & 0.102 & 0.114 & 0.107 \\
\hline
\end{tabular}

$* p$-value $<0.05 ;{ }^{* *} p$-value $<0.01 ; * * * p$-value $<0.001$

Table 5 reports the results (coefficients and $Z$-statistics in parentheses) of probit models for bond issue type (binary 0 and 1 ) over firm-specific push attributes and systematic pull factors for the period 1994-2007. Variables are defined in sections 3.2 and 3.3. 
Table 6. Different measures of relative significance of push \& pull variables

\begin{tabular}{|c|c|c|c|c|c|}
\hline \multirow{2}{*}{$\begin{array}{l}\text { Measure of } \\
\text { relative significance }\end{array}$} & \multicolumn{5}{|c|}{ Bond Type } \\
\hline & Straight & Convertible & Callable & Putable & Rule 144A \\
\hline \multicolumn{6}{|l|}{ Panel A: Regression for issue amount } \\
\hline 1. $R^{2}:$ push & 0.18 & 0.47 & 0.27 & 0.36 & 0.32 \\
\hline$R^{2}:$ pull & 0.07 & 0.05 & 0.05 & 0.14 & 0.04 \\
\hline$R^{2}:$ push + pull & 0.22 & 0.48 & 0.29 & 0.39 & 0.33 \\
\hline 2. D1 measure: push & 0.67 & 0.89 & 0.84 & 0.63 & 0.87 \\
\hline D1 measure: pull & 0.20 & 0.01 & 0.07 & 0.06 & 0.03 \\
\hline 3. Shock ratio: push & 0.65 & 0.90 & 0.77 & 0.73 & 0.84 \\
\hline Shock ratio: pull & 0.35 & 0.10 & 0.23 & 0.27 & 0.16 \\
\hline 4. Mean effects ratio: push & 0.91 & 0.99 & 0.96 & 0.94 & 0.99 \\
\hline Mean effects ratio: pull & 0.09 & 0.01 & 0.04 & 0.06 & 0.01 \\
\hline \multicolumn{6}{|l|}{ Panel B: Probit for bond type } \\
\hline 1. $R^{2}:$ push & 0.21 & 0.38 & 0.07 & 0.08 & 0.06 \\
\hline$R^{2}:$ pull & 0.05 & 0.03 & 0.03 & 0.05 & 0.05 \\
\hline$R^{2}:$ push + pull & 0.26 & 0.41 & 0.10 & 0.11 & 0.11 \\
\hline 2. D1 measure: push & 0.80 & 0.92 & 0.72 & 0.59 & 0.54 \\
\hline D1 measure: pull & 0.19 & 0.07 & 0.27 & 0.33 & 0.44 \\
\hline 3. Shock ratio: push & 0.72 & 0.86 & 0.58 & 0.62 & 0.54 \\
\hline Shock ratio: pull & 0.28 & 0.14 & 0.42 & 0.38 & 0.46 \\
\hline 4. Mean effects ratio: push & 0.77 & 0.92 & 0.79 & 0.80 & 0.68 \\
\hline Mean effects ratio: pull & 0.23 & 0.08 & 0.21 & 0.20 & 0.32 \\
\hline 5. Predicted probability: push & 0.38 & 0.60 & 0.69 & 0.19 & 0.42 \\
\hline Predicted probability: pull & 0.26 & 0.32 & 0.67 & 0.17 & 0.41 \\
\hline Predicted probability: push + pull & 0.43 & 0.62 & 0.70 & 0.22 & 0.45 \\
\hline$t$-statistic (push vs. pull) & 26.58 & 33.51 & 7.76 & 5.18 & 1.68 \\
\hline$t$-statistic (push + pull vs. push) & 16.74 & 8.58 & 8.86 & 9.87 & 13.06 \\
\hline
\end{tabular}

Table 6 reports the relative significance of push and pull variables based on different measures for regressions of bond issue offer amounts (Panel A) and probit models for bond issue type (Panel B). $R^{2}$ refers to adjusted $R^{2}$ for regressions and pseudo $R^{2}$ for probits. $D 1$ measure captures the relative explanatory power based on $R^{2}$, and shock (mean effects) ratio reflect the relative explanatory power based on $1 \sigma$ shock to $(1 \mu$ shift in) model coefficients. In Panel B, the last measure is based on the implied probabilities of issuance of each bond type based on the probit specification; $t$-statistics are based on tests of equality of predicted probabilities. 
Table 7. Bond issuance announcement effects and pull variables

\begin{tabular}{|c|c|c|c|c|c|}
\hline & \multicolumn{5}{|c|}{ Bond Type } \\
\hline & Straight & Convertible & Callable & Putable & Rule 144A \\
\hline \multicolumn{6}{|c|}{ Panel A: Average value of information content and market reaction } \\
\hline \multirow[t]{2}{*}{ IMR } & $0.99 * * *$ & $0.68 * * *$ & $0.49 * * *$ & $1.43 * * *$ & $0.91 * * *$ \\
\hline & $(81.60)$ & $(49.62)$ & $(142.46)$ & $(105.19)$ & $(148.13)$ \\
\hline \multirow[t]{2}{*}{ Issuance AR } & 0.01 & $-1.79 * * *$ & $-0.43 * * *$ & $-1.69 * * *$ & $-0.71 * * *$ \\
\hline & $(0.09)$ & $(-8.81)$ & $(-4.01)$ & $(-8.12)$ & $-(4.46)$ \\
\hline \multicolumn{6}{|c|}{ Panel B: Regression of Issuance AR on IMR and pull factors } \\
\hline \multirow[t]{2}{*}{ IMR } & 0.09 & 0.44 & 0.78 & $1.74 * *$ & $1.64 *$ \\
\hline & $(0.35)$ & $(1.27)$ & $(1.46)$ & $(2.60)$ & $(2.31)$ \\
\hline \multirow[t]{2}{*}{ Default factor } & 0.57 & $-3.02 * * *$ & 0.23 & $-2.68 * *$ & 0.04 \\
\hline & $(1.39)$ & $(-3.30)$ & $(0.49)$ & $(-2.74)$ & $(0.05)$ \\
\hline \multirow[t]{2}{*}{ Term factor } & -0.28 & 0.71 & -0.32 & $1.12 *$ & -0.45 \\
\hline & $(-1.08)$ & $(1.59)$ & $(-1.38)$ & $(2.19)$ & $(-1.25)$ \\
\hline \multirow[t]{2}{*}{ Market momentum } & 0.015 & $-0.05 * *$ & -0.01 & $-0.04 *$ & -0.01 \\
\hline & $(1.69)$ & $(-2.72)$ & $(-0.83)$ & $(-2.29)$ & $(-1.06)$ \\
\hline \multirow[t]{2}{*}{ Investor sentiment } & -0.44 & -0.46 & -0.38 & -0.60 & -0.35 \\
\hline & $(-1.86)$ & $(-1.26)$ & $(-1.78)$ & $(-1.29)$ & $(-1.06)$ \\
\hline \multirow[t]{2}{*}{ Intercept } & -0.73 & 2.43 & -0.70 & -0.86 & -1.61 \\
\hline & $(-1.42)$ & $(1.92)$ & $(-0.87)$ & $(-0.53)$ & $(-1.11)$ \\
\hline Pseudo $R^{2}$ & 0.006 & 0.009 & 0.002 & 0.017 & 0.006 \\
\hline
\end{tabular}

$* p$-value $<0.05 ; * * p$-value $<0.01 ; * * * p$-value $<0.001$

Table 7 reports the average values ( $t$-statistics in parentheses) of bond issuance information content and announcement effects (Panel A) and the results (coefficients and $t$-statistics in parentheses) of regressions of issuance announcement effects over latent information content and systematic pull factors (Panel B) for the period 1994-2007. IMR is the inverse mills ratio computed as the conditional residual in the joint probit specification in Table 5. Issuance AR is the three day announcement effect (in \%) around the bond issuance date computed as the cumulative of excess stock returns over market index returns. 